Endocrinol. Japon. 1986, 33 (3), 385-393

\title{
Activated Lymphocytes in Patients with Newly Diagnosed Type 1 (Insulin-Dependent) Diabetes Mellitus
}

\author{
Shigetaka SUGIHARA, Yoichi KOHNO, Shigeki MIYAMOTO, \\ Nozomu SASAKI, Hiroo NIIMI ANd Hironori NAKAJIMA
}

Department of Pediatrics, Chiba University School of Medicine, Chiba

\begin{abstract}
The expression of activation antigens (transferrin receptor, IL-2 receptor and Ia antigen) on circulating $\mathrm{T}$ lymphocytes from Japanese children with Type 1 diabetes was studied using five monoclonal antibodies (Ab), OKT9, anti-Tac Ab, OKIa1, anti-human HLA-DR Ab and OKT3. For detecting Ia positive $T$ cells, the dual staining technique using OKT3 and anti-Ia antibody was employed. Four out of six patients $(67 \%)$ with newly diagnosed Type 1 diabetes showed a raised level of either OKT9 or Tac positive cells when examined at diagnosis. These patients, however, rapidly lost these activation antigens after the insulin therapy was started. In contrast, in 32 long-standing patients, only $2(6 \%)$ had a high percentage of OKT9 positive cells and none of them demonstrated Tac positive cells. One out of six newly diagnosed patients or three out of 21 long-standing patients had a significantly high percentage of Ia-positive $\mathrm{T}$ cells compared with normal subjects. In poorly controlled long-standing patients whose HbA1 value was higher than $14 \%$, none of them had an increased number of activated lymphocytes. Therefore, it is unlikely that insulin deficiency and hyperglycemia were responsible for the changes observed in these studies. Activated lymphocytes might be related to activation of the immune system involved in pathogenesis of Type 1 diabetes.
\end{abstract}

Immune mechanisms have been implicated in the pathogenesis of Type 1 (insulindependent) diabetes. Lymphocytic infiltration in pancreatic islets (Gepts, 1965) and cytoplasmic and surface islet cell antibodies (Lendrum et al., 1976, Bottazzo and Doniach, 1976, Lernmark et al., 1978) have been observed in most newly diagnosed Type 1

Received January 10, 1986

Abbreviations, $\mathrm{Ab}$; antibody, FITC; fluorescein isothiocyanate, ICA; islet cell antibody, IL-2; interleukin-2, PE; phycoerythrin diabetic patients. Furthermore, several studies demonstrated that pancreatic beta cells could be destroyed or their insulin secretion could be inhibited by the administration of immunoglobulins or lymphocytes from Type 1 diabetic patients (Dobersen et al., 1980, Charles et al., 1983). These observations suggested that peripheral blood lymphocytes were actively involved in an immune process related to Type 1 diabetes.

Monoclonal antibodies allow separation of lymphocytes into subpopulations, which in turn allow a more precise study of the 
T-cell distribution in different patient groups. Studies of resting $\mathrm{T}$-cell populations using these monoclonal antibodies have revealed biologically significant alterations in the number of T-cells in various groups of Type 1 diabetes (Horita et al., 1982, Buschard et al., 1983, Galluzzo et al., 1984, Ilonen et al., 1984). Moreover, the increased number of activated $\mathrm{T}$-cells as defined by monoclonal antibodies was reported in newly diagnosed Type 1 diabetic patients (Jackson et al., 1982, Pozzilli et al., 1983, Alviggi et al., 1984, Ilonen et al., 1984, Hayward et al., 1984). Although the imbalance of T-cell subsets in patients with Type 1 diabetes mellitus was reported, there has been no precise observation about the change in the percentage of activated lymphocytes in newly diagnosed Type 1 diabetic patients before and after insulin therapy.

We studied Japanese children with newly diagnosed and long-standing Type 1 diabetes for the presence of transferrin receptor and Tac-antigen (IL-2 receptor) positive lymphocytes and Ia positive $\mathrm{T}$ cell by flow cytofluorometry. The changes in the activated $T$ cell percentage before and after insulin therapy were also studied.

\section{Materials and Methods}

\section{Subjects}

Six newly diagnosed patients with Type 1 diabetes (6 females, aged $8-13$, mean 11 years) (Table 1), 32 patients with Type 1 diabetes of long duration, ranging from one to 11 years (20 females, 12 males, aged 4-19, mean 13 years), and 23 healthy volunteers ( 14 females, 9 males, aged 6-30, mean 21 years) were studied. Clinical diagnosis of Type 1 diabetes rested on the following criteria which were proposed by National Diabetes Data Group (1979): symptoms including polyuria, polydipsia and body weight loss, random blood glucose concentration more than $200 \mathrm{mg} / \mathrm{dl}$, glycosuria and ketonuria. The duration from onset of symptoms such as polyuria and polydipsia to diagnosis of diabetes was about 2 weeks in patients $1,2,3$ and 4 , and about 2 months in cases 5 and 6 (Table 1). Insulin treatment was started on the day of diagnosis and thereafter all patients have continued with this treatment.

\section{Cell preparation}

Mononuclear cell suspensions were prepared from heparinized venous blood by Ficoll-Paque (Pharmacia Fine Chemicals) density centrifugation and washed three times in Hanks' balanced salt solution (Gibco, OH, USA). Then the cells were divided into aliquots and frozen in RPMI 1640 medium (Gibco) containing 10\% dimethyl sulphoxide (DMSO; BDH Chemicals, Poole, Eng-

Table 1. Patients with newly diagnosed Type 1 diabetes included in this prospective study

\begin{tabular}{|c|c|c|c|c|c|c|c|}
\hline \multirow[b]{3}{*}{ Case No. } & \multirow{3}{*}{$\begin{array}{l}\text { Age } \\
(\mathrm{yr})\end{array}$} & \multirow[b]{3}{*}{ Sex } & \multirow{3}{*}{$\begin{array}{l}\text { Duration } \\
\text { from onsetb) } \\
\text { to diagnosis }\end{array}$} & \multicolumn{3}{|c|}{ HbA1 $(\%)$} & \multirow{3}{*}{$\begin{array}{c}\text { Autoantibodyc) } \\
\text { ICA }\end{array}$} \\
\hline & & & & \multicolumn{3}{|c|}{$\begin{array}{l}\text { Insulin therapy } \\
\text { Before After (wk) }\end{array}$} & \\
\hline & & & & treat & $2-6$ & $12-18$ & \\
\hline 1 & 10 & $\mathrm{Fa})$ & $2 w^{d)}$ & 11.7 & & 8.4 & $(-)$ \\
\hline 2 & 11 & $\mathrm{~F}$ & 2 wk & 15.9 & 10.3 & 12.8 & $(-)$ \\
\hline 3 & 12 & $\mathrm{~F}$ & $2 \mathrm{wk}$ & 14.6 & 11.4 & 7.3 & $(-)$ \\
\hline 4 & 13 & $\mathrm{~F}$ & $2 \mathrm{wk}$ & 15.0 & 10.6 & 7.4 & $(-)$ \\
\hline 5 & 11 & F & $\left.2 \mathrm{Mo}^{\mathrm{e}}\right)$ & 21.4 & 9.7 & & $(-)$ \\
\hline 6 & 8 & $\mathrm{~F}$ & $2 \mathrm{Mo}$ & 17.1 & 11.7 & & $(-)$ \\
\hline
\end{tabular}

a) F; Female

b) The term 'onset' means the appearance of clinical signs such as polydipsia and polyuria.

c) Islet cell antibodies (ICA) were measured as described in Materials and Methods.

d) wk; weeks

e) Mo; months 
land) and $20 \%$ fetal calf serum. The frozen cells were cryopreserved at $-80^{\circ} \mathrm{C}$ until the time of the study, so that they could be under the same conditions. Prior to use, the cells were thawed rapidly at $37^{\circ} \mathrm{C}$, resuspended and washed three times with RPMI 1640 supplemented with $10 \%$ fetal calf serum. Alternatively, heparinized whole blood cells were used for staining with monoclonal antibodies. Details of variation in the procedure are given in the figure legends.

\section{Monoclonal antibodies}

Monoclonal anti-Tac antibody was kindly provided by Dr. T. Uchiyama, Kyoto University School of Medicine. Phycoerythrin (PE)-conjugated anti-Human HLA-DR was obtained from Becton Dickinson (Mountain View, CA, USA). OKIa1, OKT9 and fluorescein isothiocyanate (FITC)-conjugated OKT3 were purchased from Ortho Pharmaceutical (Raritan, NJ, USA).

\section{Staining of lymphocytes by OKT9 or anti-Tac antibody}

Aliquots of $5 \times 10^{5}$ cells in $100 \mu \mathrm{l}$ RPMI 1640 were incubated with $5 \mu \mathrm{l}$ of OKT9 or anti-Tac antibody for $30 \mathrm{~min}$ at $4^{\circ} \mathrm{C}$. After washing with phosphate buffered saline (PBS), the cells were reincubated for $30 \mathrm{~min}$ at $4^{\circ} \mathrm{C}$ with FITC conjugated goat anti-mouse IgG (Ortho Pharmaceutical) followed by washing with PBS. When whole blood cells were used for staining, the red blood cells were hemolyzed with lysing reagent. The percentage of cells positive for rim fluorescence with each monoclonal antibody was determined with flow cytofluorometry (Spectrum III; Ortho Diagnostic Systems, Inc.).

\section{Staining of Ia bearing $T$ cells}

The cells were stained by a dual staining technique using PE-conjugated anti-human HLADR and FITC-conjugated OKT3. Cell suspension $(100 \mu \mathrm{l})$ was incubated with $5 \mu \mathrm{l}$ of PEconjugated anti-human HLA-DR antibody for $30 \mathrm{~min}$ at $4^{\circ} \mathrm{C}$. After washing with PBS, the cells were reincubated for $30 \mathrm{~min}$ at $4^{\circ} \mathrm{C}$ with $10 \mu 1$ of FITC-conjugated OKT3, followed by washing with PBS. Alternatively, whole blood cells were stained by a dual staining technique using OKIa1 and FITC-conjugated OKT3. Whole blood cells were incubated for $30 \mathrm{~min}$ at $4^{\circ} \mathrm{C}$ in the presence of monoclonal antibody OKIa1, washed twice, and then biotin conjugated goat anti-mouse IgG (Tago Inc., Burlingame, CA, USA) was added, followed by incubation for $30 \mathrm{~min}$ at $4^{\circ} \mathrm{C}$. After washing, the cells were incubated with saturating amounts of mouse IgG (Cappel, Cochranville, PA, USA) for $10 \mathrm{~min}$, and PEconjugated avidin (Becton Dickinson, Mountain View, CA, USA) and FITC-conjugated OKT3 were added. This was followed by incubation for $30 \mathrm{~min}$ at $4^{\circ} \mathrm{C}$, hemolysis and washing. All samples were analyzed by flow cytofluorometry. Results were expressed as mean \pm SD unless otherwise stated.

\section{Metabolic studies}

Blood glucose was measured by a hexokinase method and HbA1 by agar gel electrophoresis (Menard et al, 1980). Islet cell antibodies (ICA) were determined according to the method Bottazzo et al. (1974).

\section{Statistics}

Statistical analysis of the results was performed with Fisher's exact test. A significant increase in the percentage of activation antigenpositive lymphocytes was taken as over two standard deviations above the mean value for the level in normal controls.

\section{Results}

Increase in the activated T-lymphocyte percentage

Three of five patients (case 1,2 and 6) had a significant increase in the percentage of OKT9 positive cells ranging from 1.6 to $13.0 \%$ at diagnosis, before the start of insulin therapy (Table 2). However, within 2 weeks after insulin therapy, the percentage of their OKT9 positive cells decreased. The raised level of OKT9 positive cells was demonstrated until 26 weeks after the start of insulin therapy in one patient (case 3). On the other hand, only 2 patients out of 32 patients with long-standing Type 1 diabetes had a raised level of OKT9 positive cells (Fig. 1).

One patient (case 4) out of four patients examined at diagnosis had an increase in the percentage of Tac-positive cells (Table 3 ). Case 1 showed a relatively high percentage 
Table 2. Percentage of OKT9 positive cells before and after insulin therapy in newly diagnosed Type 1 diabetics

\begin{tabular}{|c|c|c|c|c|c|c|}
\hline \multirow[b]{2}{*}{ Case No. } & \multirow{2}{*}{$\begin{array}{l}\text { Before } \\
\text { therapy }\end{array}$} & \multicolumn{4}{|c|}{ After insulin therapy (wk) } & \multirow{2}{*}{$\begin{array}{l}\text { Normal subjects } \\
\text { Mean } \pm \text { SD (n)c) }\end{array}$} \\
\hline & & 1 & $2-6$ & $12-18$ & 26 & \\
\hline \multicolumn{7}{|l|}{ Exp. 1} \\
\hline 1 & $3.1 \mathrm{a})$ & 1.3 & $\left.\mathrm{NT}^{\mathrm{b}}\right)$ & 1.4 & NT & \\
\hline 2 & $1.6^{\mathrm{a})}$ & 1.1 & 1.0 & 0.5 & NT & \\
\hline 3 & 1.5 & $3.0^{\mathrm{a})}$ & $1.7 \mathrm{a})$ & 0.8 & $2.2^{\mathrm{a})}$ & $0.7 \pm 0.4(8)$ \\
\hline 4 & 1.2 & 0.5 & 0.6 & 0.6 & NT & \\
\hline 5 & NT & 1.1 & 0.4 & NT & NT & \\
\hline \multicolumn{7}{|l|}{ Exp. 2} \\
\hline 6 & $13.0 \mathrm{a})$ & 0.1 & 0.2 & NT & NT & $0.3 \pm 0.3$ \\
\hline
\end{tabular}

a) percentage over $2 \mathrm{SD}$ above the normal mean value.

b) NT; not tested

c) $\mathrm{n}$; number

In experiment 1 , mononuclear cells were cryopreserved at $-80^{\circ} \mathrm{C}$ until the study. In experiment 2, whole blood cells were used for staining.

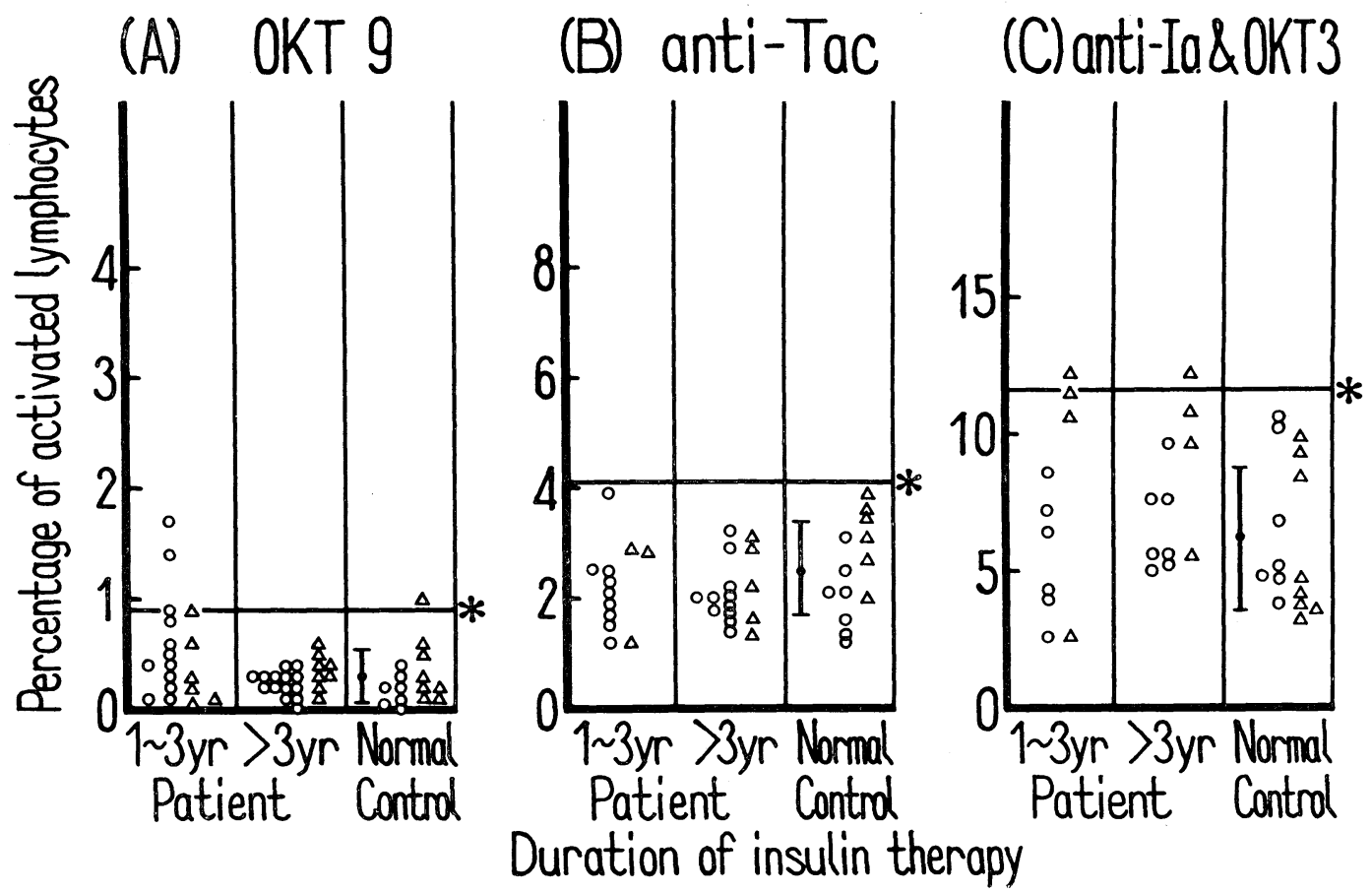

Fig. 1. Activated lymphocytes in long-standing patients with Type 1 diabetes and healthy controls. Thirty-two patients with Type 1 diabetes of long duration (more than 1 year) were examined. One hundred $\mu 1$ of whole blood was incubated wtih each monoclonal antibody as described in Materials and Methods.

$\bigcirc$; female case. $\triangle$; male case. $*$; percentage of $2 \mathrm{SD}$ above the normal mean value. I; mean $\pm \mathrm{SD}$. 
Table 3. Percentage of Tac positive cells before and after insulin therapy in newly diagnosed Type 1 diabetics

\begin{tabular}{|c|c|c|c|c|c|c|}
\hline \multirow[b]{2}{*}{ Case No. } & \multirow{2}{*}{$\begin{array}{l}\text { Before } \\
\text { therapy }\end{array}$} & \multicolumn{4}{|c|}{ After insulin therapy (wk) } & \multirow{2}{*}{$\begin{array}{l}\text { Normal subjects } \\
\text { Mean } \pm S D(n) c)\end{array}$} \\
\hline & & 1 & $2-6$ & $12-18$ & 26 & \\
\hline \multicolumn{7}{|l|}{ Exp. 1} \\
\hline 1 & 2.4 & 2.1 & $\left.N^{b}\right)$ & 1.8 & NT & \\
\hline 2 & 1.2 & 1.7 & 1.6 & 1.0 & NT & \\
\hline 3 & 2.1 & 1.7 & 0.5 & 1.8 & 1.7 & $1.6 \pm 0.4(7)$ \\
\hline 4 & $2.9 \mathrm{a})$ & 2.4 & 2.4 & 2.0 & NT & \\
\hline 5 & NT & 2.3 & 1.8 & NT & NT & \\
\hline \multicolumn{7}{|l|}{ Exp. 2} \\
\hline 6 & NT & $4.3^{\mathrm{a})}$ & 1.7 & NT & NT & $2.5 \pm 0.8$ \\
\hline
\end{tabular}

a) percentage over $2 \mathrm{SD}$ above the normal mean value.

b) NT; not tested

c) $\mathrm{n} ;$ number

In experiment 1 , cryopreserved lymphocytes were used for staining whereas whole blood cells

were used in experiment 2.

of Tac positive cells but it was not statistically significant (Table 3). Furthermore, one of six newly diagnosed patients, case 6 , had an increase in the percentage of Tac positive cells within $1 \mathrm{wk}$ after insulin therapy, but thereafter no increase in this percentage was observed. In a group of 27 patients with long-standing Type 1 diabetes, none had an increase in the number of Tac positive cells (Fig. 1). The differences between the incidence of a raised level of either OKT9 or Tac positive cells in newly diagnosed patients (4/6) and in long-standing patients $(2 / 32)$, were statistically significant ( $\mathrm{P}<0.01$, by Fisher's exact test $)$. The percentage of cells stained with OKT9 was not correlated with that stained with anti-Tac $\mathrm{Ab}(\mathrm{r}=0.237, \mathrm{P}>0.05$, Fig. 2).

The percentage of Ia-positive $T$ cells in newly diagnosed patients ranged from 5.1 to $9.6 \%$ (Table 4). Five patients had no increase in the percentage of Ia-positive $\mathrm{T}$ cells at diagnosis compared with normal controls. One patients (case 6) had a significantly high percentage of Ia-positive $\mathrm{T}$ cells $(12.5 \%)$ at 6 weeks after insulin therapy. Three patients with 21 long-standing Type 1 diabetes had a raised level of Iapositive $\mathrm{T}$ cells (Fig. 1).

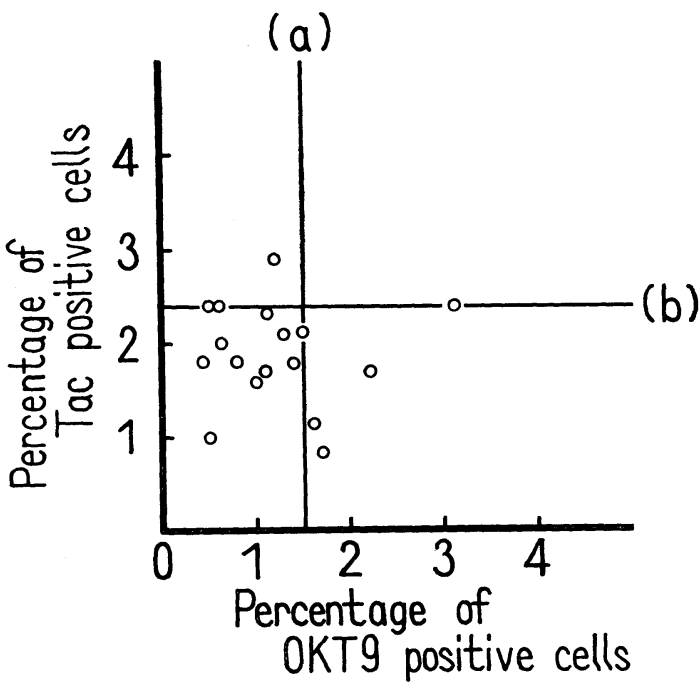

Fig. 2. Relationship between OKT9 positive cells and Tac-positive cells in the peripheral blood lymphocytes of newly diagnosed Type 1 diabetic patients. Percentages of OKT9 and Tac positive cells measured at each time before and after the start of insulin therapy of six patients shown in Table 2 and 3 are plotted. (a): percentage of 2SD above the normal mean value of OKT9 positive cells. (b): percentage of 2SD above the normal mean value of Tac positive cells. 
Table 4. Percentage of Ia-positive $\mathrm{T}$ cells before and after insulin therapy in newly diagnosed Type 1 diabetics

\begin{tabular}{ccccccc}
\hline \hline Case No. & $\begin{array}{l}\text { Before } \\
\text { therapy }\end{array}$ & 1 & $\begin{array}{c}\text { After insulin } \\
2-6\end{array}$ & $\begin{array}{c}\text { therapy (wk) } \\
12-18\end{array}$ & 26 & $\begin{array}{c}\text { Normal subjects } \\
\text { Mean } \pm \text { SD (n)c }\end{array}$ \\
\hline Exp. 1 & & & & & & \\
1 & 5.2 & 4.5 & $\left.\mathrm{NT}^{\mathrm{b}}\right)$ & 5.6 & $\mathrm{NT}$ & \\
2 & 5.0 & 3.3 & 2.3 & 2.3 & $\mathrm{NT}$ & \\
3 & 5.1 & $\mathrm{NT}$ & $\mathrm{NT}$ & 3.4 & 2.8 & $5.9 \pm 2.3(8)$ \\
4 & 9.2 & 7.0 & 7.5 & 8.7 & $\mathrm{NT}$ & \\
5 & $\mathrm{NT}$ & 3.0 & 2.7 & $\mathrm{NT}$ & $\mathrm{NT}$ & \\
Exp. 2 & & & & & & \\
6 & 9.6 & 7.6 & $12.5 \mathrm{a})$ & $\mathrm{NT}$ & $\mathrm{NT}$ & $6.2 \pm 2.7(15)$ \\
\hline
\end{tabular}

a) percentage over $2 \mathrm{SD}$ above the normal mean value.

b) NT; not tested

c) $\mathrm{n}$; number

In experiment 1 , cryopreserved lymphocytes were used for staining whereas whole blood cells were used for staining in experiment 2. Percentage of Ia positive T cells was calculated according to the following equation:

$\%$ of Ia-positive $\mathrm{T}$ cells $=\frac{\text { Both Ia and OKT3 positive cells }}{\text { All OKT3 positive cells }} \times 100$

(A) OKT 9

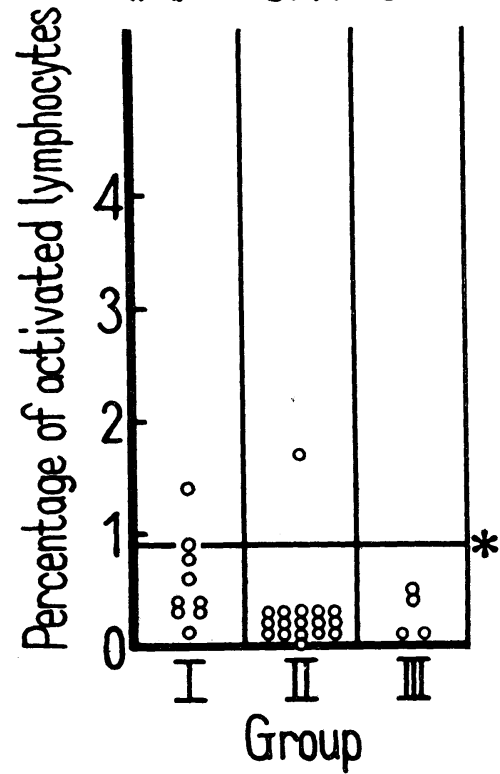

(B) anti-Tac

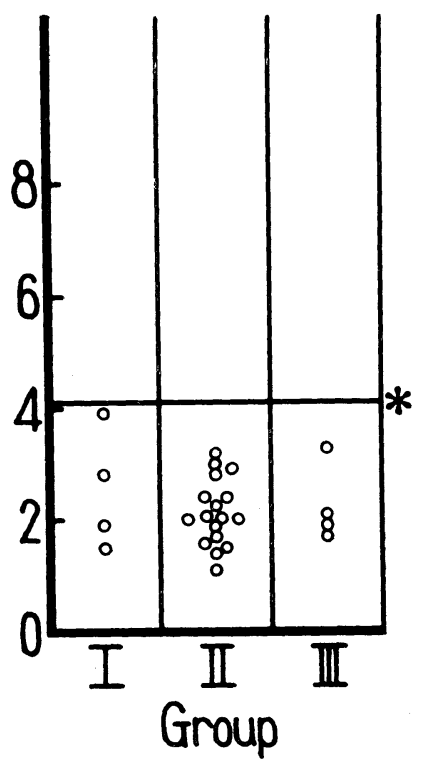

(Clanti-Ia\&OKT3

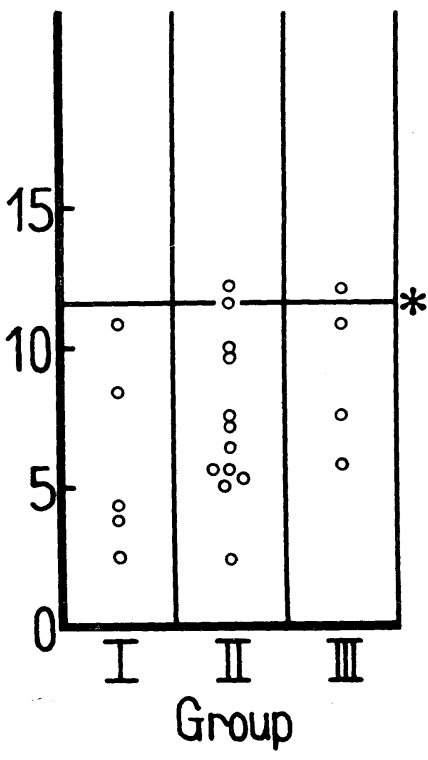

Fig. 3. Activated lymphocytes in long-standing patients with Type 1 diabetes: Influence of metabolic control. Thirty-two patients with Type 1 diabetes of long duration (more than 1 year) were examined as described in Materials and Methods. Metabolic condition was determined by the values of $\mathrm{HbA} 1$, with which patients were divided into 3 groups. Group I: $\mathrm{HbA} 1<10 \%$, Group II : $10 \% \leqq \mathrm{HbA} 1<14 \%$, Group III : HbA1 $\geqq 14 \%$. Patients in group III were considered to be poorly controlled.

*; percentage of $2 \mathrm{SD}$ above the normal mean value. 


\section{Influence of metabolic control}

There was no correlation between the level of activated lymphocytes and the values for $\mathrm{HbAl}$ in patients with longstanding Type 1 diabetes (Fig. 3). All four poorly controlled patients with $\mathrm{HbA1}$ values larger than $14 \%$ had no raised level of OKT9 or Tac positive cells (panel A, B, Fig. 3). One of them had a raised level of Ia-positive T cells (panel C, Fig. 3).

\section{Discussion}

The majority of $\mathrm{T}$ cells from normal persons, when activated in vitro by mitogens, express a series of functional antigens, such as the Ia antigen, transferrin receptor, Tac antigen which is interleukin 2 (IL-2) receptor and insulin receptor. Monoclonal antibodies OKT9 and anti-Tac antibodies were reported to recognize the transferrin receptor (Sutherland et al., 1981) and IL-2 receptor (Leonard et al., 1982), respectively. Anti-human HLADR antibody, obtained from the clone L243 and OKIa1 reportedly recognized the nonpolymorphic HLA-DR determinants (Lampson et al., 1980, Schlossman et al., 1976).

Increased percentages of Ia antigen positive E-rosetting blood lymphocytes have been found in Type 1 diabetes within 6 months of diagnosis (Jackson et al., 1982, Alviggi et al., 1984). Pozzili et al. (1983) reported an increased number of activated $\mathrm{T}$ cells as defined by monoclonal antibody $4 \mathrm{~F} 2$ in newly diagnosed Type 1 diabetic patients. Hayword et al. (1984) found an increase in the percentage of Tac-positive lymphocytes in Type 1 diabetic patients within 2 years of diagnosis, compared with that in patients whose Type 1 diabetes was of 3 or more years, or in healthy controls. On the other hand, Ilonen et al. (1984) demonstrated no raised level of Ia-positive $\mathrm{T}$ cells in newly diagnosed-Type 1 diabetes. To the best of our knowledge, however, no earlier studies have demonstrated a change in the percen- tage of transferrin receptor and Tac positive circulating cells prospectively before and after the insulin therapy in Type 1 diabetic patients. In our study, sixty seven percent (4/6) of patients with newly diagnosed Type 1 diabetes showed a raised level of either OKT9 or Tac positive cells when examined at diagnosis. Our findings about Ia-positive $\mathrm{T}$ cells in Type 1 diabetes are in accordance with the results shown by Ilonen et al. but not with those reported by Jackson et al. and Alviggi et al.

The following possibilities could be considered to account for the discrepancy in the results of circulating Ia-positive $\mathrm{T}$ cells in patients with Type1 diabetes. (a) We studied children with recent onset Type 1 diabetes whose ages ranged from 8 to 13 years. On the other hand, earlier studies involved adult patients. Jackson et al. (1983) demonstrated that adults (above age 18) rather than children with new onset Type 1 diabetes had elevated Ia-positive $\mathrm{T}$ cells; (b) It is known that neither transferrin receptor nor Tac antigens appear on resting lymphocytes, but Ia antigens mainly appear on all B lymphocytes and on some monocytes. Therefore, $T$ cell purification is a major technical problem related to the quantitation of Ia-positive $T$ cells. In previous studies (Jackson et al., 1982, Alviggi et al., 1984, Ilonen et al., 1984), $T$ cell preparation was performed by rosetting with neuraminidase-treated sheep erythrocytes. By using this method, some monocytes or $\mathrm{B}$ cells might contaminate $\mathrm{T}$ cell preparations. We utilized the dual staining technique using OKT3 and anti-Ia antibodies to avoid an increase in background secondary to the contamination of B cells and monocytes counted as the activated lymphocytes by flow cytofluorometry, which provided a high degree of accuracy. Forty-five to $55 \%$ of lymphocytes from normal individuals stimulated with Con A were defined as Ia-positive $\mathrm{T}$ cells by the dual staining technique (data not shown). 
The monoclonal antibody OKT3 reacting with mature $\mathrm{T}$ cell marker instead of OKT11 recognizing sheep erythrocyte receptor on $T$ cells was used in these studies. Therefore, the possibility that OKT3 dull or negative and OKT11 positive $T$ cells express Ia antigen on their surface could not be excluded.

It should be considered whether the rise in activated lymphocytes could be due to the insulin deficiency and metabolic derangement in diabetes mellitus since the percentage of OKT9 and Tac positive lymphocytes showed a tendency to decrease after insulin therapy. Our observations suggest that metabolic derangement in diabetes mellitus was an unlikely cause of the rise in the level of activated lymphocytes. Insulin is an immunomodulating molecule (Helderman, 1981) whose receptor on lymphocyte is known to be one of the activation antigens. Therefore we could not exclude the possible direct effect of insulin on the decrease in the percentage of OKT9 or Tac positive lymphocytes in newly diagnosed Type 1 diabetes within a few weeks after the start of insulin therapy.

The pathogenic significance of these circulating activated lymphocytes in Type 1 diabetes is poorly understood. These activated cells are not specific for Type 1 diabetes. However, it is likely that activated lymphocytes are related to activation of the immune system which results in the destruction of pancreatic beta cells in Type 1 diabetic patients.

\section{Acknowledgments}

We are grateful to Ortho Diagnostic Systems Inc. for the use of Spectrum III. We thank Dr. T. Uchiyama, Kyoto University School of Medicine, Kyoto, for the gift of anti-Tac antibody and Dr. Shinjo, Tokyo Women's Medical College, Tokyo, for the assay of ICA.

\section{References}

Alviggi, L., C. Johnston, P. J. Hoskins, D. E. H. Tee, D. A. Pyke, R. D. G. Leslie and D. Vergani (1984). Pathogenesis of insulindependent diabetes; $A$ role for activated $T$ lymphocytes. Lancet 2, 4-6.

Boitard, C., M. Debray-Sachs, A. Pcuplard, R. Assan and J. Hamburger (1981). Lymphocytes from diabetics suppress insulin release in vitro. Diabetologia 21, 41-46.

Bottazzo, G. F., A Florin-Christian and D. Doniach (1974). Islet-cell antibodies in diabetes mellitus with autoimmune polyendocrine deficiencies. Lancet ii, 1279-1282.

Bottazzo, G. F. and D. Doniach (1976). Pancreatic autoimmunity and HLA antigens. Lancet 2,800 .

Buschard, K., C. Ropke, S. Madsbad, J. Mehlsen and J. Rygaard (1983). T lymphocyte subsets in patients with newly diagnosed type 1 (insulin-dependent) diabetes; a prospective study. Diabetologia 25, 247-251.

Charles, M. A., M. Suzuki, N. Waldeck, L. E. Dodson, L. Slater, K. Ong, A. Kershnar, B. Buckingham and M. Golden (1983). Immune islet killing mechanisms associated with insulindependent diabetes; In vitro expression of cellular and antibody-mediated islet cell cytotoxicity in humans. J. Immunol. 130, 1189-1194.

Dobersen, M. J., J. E. Scharff, F. GinsbergFellner and A. L. Notkins (1980). Cytotoxic autoantibodies to beta cells in the serum of patients with insulin-dependent diabetes mellitus. N. Engl. J. Med. 303, 1493-1498.

Galluzzo, A., C. Giordano, G. Rubino and G. D. Bompiani (1984). Immunoregulatory $T$ lymphocyte subset deficiency in newly diagnosed Type 1 (insulin-dependent) diabetes mellitus. Diabetologia 26, 426-430.

Gepts, W. (1965). Pathologic anatomy of the pancreas in juvenile diabetes mellitus. Diabetes 14, 619-633.

Hayward, A. R. and M. Herberger (1984). Culture and phenotype of activated T-cells from patients with Type 1 diabetes mellitus. Diabetes 33, 319-323.

Helderman, J. H. (1981). The role of insulin in the intermediary metabolism of the activated thymic derived lymphocyte. J. Clin. Invest. 67, 1636-1642. 
Horita, M., H. Suzuki, T. Onodera, F. GinsbergFellner, A. S. Fauci and A. L. Notkins (1982). Abnormalities of immunoregulatory $\mathrm{T}$ cell subsets in patients with insulin-dependent diabetes mellitus. J. Immunol. 129, 1426-1429.

Ilonen, J., H.-M. Surcel, A. Mustonen, M. L. Käär and H. K. Åkerblom (1984). Lymphocyte subpopulations at the onset of Type 1 (insulindependent) diabetes. Diabetologia 27, 106-108.

Jackson, R. A., M. A. Morris, B. F. Haynes and G. S. Eisenbarth (1982). Increased circulating Ia-antigen-bearing $\mathrm{T}$ cells in Type 1 diabetes mellitus. N. Engl. J. Med. 306, 785-788.

Jackson, R. A., S. Srikanta, M. A. Morris, R. Dolinar, T. Aoki and G. S. Eisenbarth (1983). Immunologic subgroups of Type 1 diabetes; $92 \%$ of adults have $\mathrm{Ia}^{+} \mathrm{T}$ cells (abstract). Clin. Res. 31, 388A.

Lampson, L. A. and R. Levy (1980). Two populations of Ia-like molecules on a human B cell line. J. Immunol. 125, 293-299.

Lendrum, R., G. Walker, A. G. Cudworth, J. C. Woodrow and D. R. Gamble (1976). HLAlinked genes and islet-cell antibodies in diabetes mellitus. Br. Med. J. 1, 1565-1567.

Leonard, W. J., J. M. Depper, T. Uchiyama, K. A. Smith, T. A. Waldmann and W. C. Greene (1982). A monoclonal antibody that appears to recognize the receptor for human T-cell growth factor; partial characterization of the receptor. Nature 300, 267-269.

Lernmark, A., Z. R. Freeman, C. Hoffmann,
A. H. Rubenstein, D. F. Steiner, R. L. Jackson, R. J. Winter and H. S. Traisman (1978). Isletcell-surface antibodies in juvenile diabetes mellitus. N. Engl. J. Med. 299, 375-380.

Menard, L., M. E. Dempsey, L. A. Blankstein, H. Aleyassine, M. Wacks and J. S. Soeldner (1980). Quantitative determination of glycosylated hemoglobin $A_{1}$ by agar gel electrophoresis. Clin Chem. 26, 1598-1602.

National Diabetes Data Group (1979). Classification and diagnosis of diabetes mellitus and other categories of glucose intolerance. Diabetes 28, 1039-1057.

Pozzilli, P., O. Zuccarini, M. Iavicoli, D. Andreani, M. Sensi, K. M. Spencer, G. F. Bottazzo, P. C. L. Beverley, J. L. Kyner and A. G. Cudworth (1983). Monoclonal antibodies defined abnormalities of T-lymphocytes in Type 1 (insulin-dependent) Diabetes. Diabetes 32, 91-94.

Schlossman, S. F., L. Chess, R. E. Humphreys and J. L. Strominger (1976). Distribution of Ia-like molecules on the surface of normal and leukemic human cells. Proc. Natl. Acad. Sci. USA 73, 1288-1292.

Sutherland, R., D. Delia, C. Schneider, R. Newman, J. Kemshead and M. Greaves (1981). Ubiquitous cell-surface glycoprotein on tumor cells is proliferation-associated receptor for transferrin. Proc. Natl. Acad. Sci. USA 78, 4515-4519. 